に寄与したことが推定される.

\section{6. おわりに}

近年の沿岸開発は干潟をなくし，砂浜をなくす ことで海域が本来持っている自浄能力を低下させ る傾向にある。ここで紹介した海洋浄化装置は自 然の浄化能力の補助をするものにすぎない．従っ て，稼動と同時に劇的に効果を現すものではなく， 少しずつ, やさしく作用するものである．今後， 自然環境の改善に工学的技術が利用される場は増 えてゆくと思われる。しかし，その際に密度の濃 いエネルギーを投入し，劇的な効果を期待する方 法をとると, 生態系のバランスを崩し, 本来の環 境を変化させる危険も大であることに注意が必要 である．また，対象となる海域は場所によって性 格が異なり，生息生物や現象にも差があることも 忘れてはならない.

いずれにしても海洋浄化技術開発は海域への流 入負荷削减のための行政, 企業, 個人の努力と平 行して進められる必要がある.

\section{参考文献}

1）浅枝隆 外：水面に衝突する高密度噴流の拡がり幅, 土木学会論文集 第411号／II－12 1989年

2）飯塚昭二 外：大村湾における無酸素水塊の形成, 沿 岸海洋研究ノート第26巻第2号 1989 年

3） 日本全国沿岸海洋誌 第 22 章 大村湾 東海大学出版 1985年

\section{シンポジウムを終えで*}

\section{寺田 政 信**}

当日は, 多数の方々の参加をいただき, 改めて お礼を申し上げます。

海洋機器研究委員会として「海洋開発の新技術」 のテーマでシンポジウムを開催した.

海洋機器研究委員会では, 幅広い海洋開発分野 を下記の 10 項目に分類して, 調查研究を進めてい る.

*原稿受付 平成 9 年 11 月 4 日

$* *$ 正会員 関西設計株式会社 (大阪市北区本庄東 $1-1-10$ )
（1） 海洋エネルギー

(2) 海洋環境問題

（3） 海洋石油開発

（4）海洋鈗物資源

（5） 海洋生物資源

（6）海洋空間利用

(7) マリン・バイオテクノロジー

（8）海洋土木·水中作業

(9) 海洋観測

（10）海外における海洋開発状況

このシンポジゥムでは，(2)関連が2件，(3)関 連が 2 件，（6）関連が 1 件，（9）関連が 1 件となって いる.

なお, シンポジウムで取り上げなかった分野に ついては, 海洋開発特集号 (本月号)の「展望」, 「解説」の項目で，それぞれの分野で活躍している 執筆者にお願いし, 最新の情報を提供いただいて いる.

シンポジゥムで取り上げた各項目について，総 括する.

「無人探査機の最新技術について」では，1万 m 級無人探査機「かいこう」に採用された, 光ファイ バーケーブルを用いた強靶なテザーケーブルや強 大な圧力に耐えるシンタクテックフォーム浮力材 など日本が世界に誇る先端技術の紹介があった。

また, 無索無人潜水用水中動力源として, 最近 開発された長寿命, 高性能のリチウム・イオン電 池についても紹介があった.

この海洋調査の分野では, 深海域では, 「しんか 6500 」と今回発表の「かいこう」等, 広海域では, 最 近就航した海洋観測研究船「みらい」等が活躍して いる. また, 将来にわたっては,「21世紀の深海掘 削計画」が提案され, 当面水深 $2,500 \mathrm{~m}$ のところで ライザー掘削のできる深海掘削船の計画が進行中 である。

今や日本は海洋調査の分野では世界のトップク ラスといえる.

「第五世代大型セミサブ オイルリグにおける新 しい技術では，2000年には，石油の需給が逼迫す るであろうとの予測を裏付けるように，現有のリ グの大水深へのアップグレード改造が進んでおり， 海洋石油開発活性化の兆しがうかがえる.

この背景には，石油探査技術／彩油技術の進歩 と FPSOに代表される効率的石油生産設備の実用 
化があるといえる.

また, 最近大型セミサブオイルリグが発注され, その性能も第五世代リグにふさわしいもので，ラ ムリグなど新しい技術も採用されている.

このような大水深を対象としたオイルリグがこ れからも連続して発注されるのか注目したい.

「浮遊式LPG貯蔵積出設備」では, 最近原油を対 象としたFPSO, FSOが急增している中で, LPGを 対象としたFSOの紹介があった。

低温貨油を扱うので，原油対象のFSO /FPSO とは異なった特殊要件があり，技術的にもいろい ろの工夫のあとがみられた。

今後, 石油基地から遠い中小規模のガス田の開 発では, 洋上で夜化したり, メタノールにしたり する方式が採用されると予測される。この場合， LPG，LNGやメタノールを対象としたFSOや FPSO が建造されるであろう. 今回のLPGのFSO は世界最初の実績として評価できる.

「メガフロート水中部施工支援機器の最新技術」 では, 昨今話題のメガフロートの建造, 運用, 保 守などに活躍する支援機器の最新技術について紹 介があった. 非常に広範囲な洋上接合用水中部施 工支援機器の各種チェンバー/ワークベッセル, 水中部補修の支援機器など一見脇役に見えるが， メガフロートの実用化プロジェクトの実現のため には欠かせない技術であるといえる。

「海洋の油污染防止」では, 平成 9 年 1 月 2 日に発 生したナホトカ号油流出事故の反省も踏まえて, 改めて海洋の油污染を防止するにはどうすべきか についての提言でした。
海洋油污染防止策を考える場合の前提について はともすれば現実に不可能な情緒的な意見の多い 中, 現実的な数字で提案されている.その上に立 つて, 海洋油污染の全体像について提言がなされ ている.

ナホトカ号の事故が風化しつつある今日，同じ 過ちを繰り返さないためにも貴重な提言であった と思う。「海洋浄化装置の開発」では，特に閉鎖， または閉鎖に近い海域で生活排水や農畜産排水が 原因で起こる富栄養化現象, それにともなう貧酸 素化現象を抑制する, 自然エネルギーを利用した 海洋浄化装置の紹介があった.

まず水理実験で現象の実体を確認し，その上で， 波力利用の海洋浄化装置と風力利用の海洋浄化装 置を提案している。このような自然に優しい浄化 装置は, 湾や入江の多い日本に必要な海洋機器だ と思う。

今まで述べてきたように, 海洋機器研究委員会 は幅広い海洋分野について, 運輸省 船舶研究所, 海洋科学技術センター, 民間会社の技術研究所, 海洋関連の講座を持つ各種学校などの協力をえて 調査研究を進めている.

当研究会への参加はオープンとなっているので, 若い技術者の参加に期待したい. 会員諸氏の協力 をお願いしたい.

最後にシンポジゥムで発表して頂いた方々，会 場設定, 進行をしていただいた神戸商船大学の関 係者, 舶用機関学会事務局の方々に改めてお礼を 申し述べる。 